\title{
ROLE OF PLANT PROBIOTICS, SUCROSE AND SILICON IN THE PRODUCTION OF TOMATO (SOLANUM LYCOPERSICUM L.) SEEDLINGS UNDER HEAT STRESS IN A GREENHOUSE
}

\author{
El-Aidy, F. ${ }^{1}-$ ABDAlla, M. ${ }^{2}-$ EL-SAWY, M. ${ }^{1}-$ El KADY, S. A. ${ }^{2}-$ BAYOUMI, Y. $.^{1,3^{*}}-$ EL- \\ RAMADY, $\mathrm{H}^{4}$ \\ ${ }^{1}$ Horticulture Dept., Faculty of Agriculture, Kafrelsheikh University, Kafrelsheikh, Egypt \\ (e-mails:farouk.elaidi@agr.kfs.edu.eg; mohamed_ElSawy@agr.kfs.edu.eg; \\ sohairelkady010@gmail.com) \\ ${ }^{2}$ Vegetable Crops Research Dept., Horticulture Research Institute, Agriculture Research Center \\ (ARC), Giza, Egypt \\ (e-mail:manalabd2002@yahoo.co.uk) \\ ${ }^{3}$ Physiology \& Breeding of Horticultural Crops Laboratory, Horticulture Dept., Faculty of \\ Agriculture, Kafrelsheikh University, Kafrelsheikh, Egypt \\ ${ }^{4}$ Soil and Water Dept., Faculty of Agriculture, Kafrelsheikh University, Kafrelsheikh, Egypt \\ (e-mail: hassanelramady@rocketmail.com) \\ *Corresponding author \\ e-mail: ybayoumi2002@yahoo.com.sg
}

(Received $4^{\text {th }}$ Jun 2020; accepted 20 $0^{\text {th }}$ Aug 2020)

\begin{abstract}
The rising temperature and global warming is a great challenge our planet facing nowadays. The production of vegetables in a greenhouse system under high temperatures could also be considered a vital threat for arid zones in particular. This study was carried out during two successive summer seasons under greenhouse conditions. The effect of different amendments including plant probiotics, silicon, sucrose and paclobutrazol were investigated on growth and quality of tomato seedlings under heat stress in a greenhouse. The main findings of this study were the followings: foliar applications of plant probiotics $\left(100 \mathrm{mg} \mathrm{l}^{-1}\right)$ resulted in the tallest seedlings followed by sucrose $(10 \%)$ and silicon $\left(500 \mathrm{mg} \mathrm{l}^{-1}\right)$ treatments 28 and 35 days after sowing (DAS), whereas the shortest seedlings were obtained from the treatments of the control, silicon $\left(100 \mathrm{mg} \mathrm{l}^{-1}\right)$ and paclobutrazol $\left(100 \mathrm{mg} \mathrm{l}^{-1}\right)$. There were significant differences among all treatments for chlorophyll content, at both growth stages and after 28 and 35 DAS in both seasons in most cases. Tomato seedlings could overcome the high temperature stress under greenhouse conditions, with foliar application of plant probiotics, sucrose and silicon. Further studies are needed focusing on the gene expression and biochemical traits under previous treatment conditions.
\end{abstract}

Keywords: high-temperature stress, seedling quality, chlorophyll, healthy seedlings, abiotic stress, vegetative growth, NPK contents, agro-chemical compounds, climate change

\section{Introduction}

Tomato (Solanum lycopersicum L.) is considered a popular vegetable worldwide. This Solanaceous seedling has categorized as an important model plant in investigating the stress tolerance (Zhang et al., 2018; Alturki et al., 2020). So, several stress studies have been carried out on tomato seedlings such as heat stress (Lyu et al., 2018), water stress (Zhang et al., 2018), drought (Bian et al., 2019), salinity (Zhou et al., 2019), UVB stress (Liu et al., 2020), chilling (Dong et al., 2020), and waterlogging (Elkelish et al., 2020). Many strategies could be adapted to overcome these stresses depending on the kind of stress, cultivated plants and its growth stage (Zhou et al., 2020). Many 
researchers reported about these strategies in the case of tomato seedlings, which include application of spermidine (Sang et al., 2016), calcium, magnesium and potassium compounds (Sakhonwasee and Phingkasan, 2017; Nafees et al., 2019), ascorbic acid (Alayafi, 2020), melatonin and salicylic acid (Jahan et al., 2019a, b) as well as proline (Tonhati et al., 2020).

Egypt is ranked the fifth country worldwide in 2018 concerning tomato production $(6,624,733 \mathrm{Mg})$, the area harvested was 161,702 ha and the yield recorded $40.96 \mathrm{Mg} \mathrm{ha}^{-}$ ${ }^{1}$ (FAOSTAT, 2020). So, the high quality of tomato seedlings and its transplantation are common practice in successful production of tomatoes for fast sustainable establishment coupled with enhancement of earliness, uniform maturity and total yield as well as quality (FAO, 2017). Therefore, the production of healthy and vigorous tomato seedlings is the most important factor controlling this successful commercial production and the quality of tomato fruits (Gama et al., 2015; El-Shafeey et al., 2019). The produced seedlings also should be hardened to increase stress resistance by increasing content of carbohydrates, dry matter, and thickness of the wax layer as well as reducing plant size, water loss and slowing plant growth (Hossain et al., 2020). This target could be achieved by spraying the seedlings with some solutions such as paclobutrazol (Zhao et al., 2017; Zhang et al., 2019) and silicon (Zhang et al., 2018).

Climate change and global warming are serious problems threatening the agricultural production. The global temperature is projected to increase with a rate that may reach 1.5 and $3.5^{\circ} \mathrm{C}$ by 2050 and 2100 , respectively (Zhou et al., 2020). The high temperature or heat stress is considered one of the most devastating abiotic stresses, which becomes more serious due to global warming (Bilal et al., 2020). High temperature stress may disturb cellular homeostasis, affect physiological and biochemical reactions, as a consequence, it impedes plant growth, development and eventually reduces crop productivity (Fahad et al., 2017). Concerning the impact of high temperature on tomato, it is reported that the tomato growth may be impeded during the summer period threatening the yield (Zhou et al., 2020).

Silicon is considered the second abundant element in the earth's crust (28\%) after oxygen $(47 \%)$. There is no evidence that silicon is essential for growth of higher plants but this element has distinguished and beneficial roles as "quasi-essential element" in promoting the cultivated plants under different stresses (Zargar et al., 2019; Cao et al., 2020). Silicon can ameliorate the negative effects of stress (e.g., heat stress, drought and water stress) through improving the physiological and biochemical features of tomato (Zhang et al., 2018; Cao et al., 2020). Several studies have been published on the silicon and its roles in tomato production under different stresses (e.g., Li et al., 2015; Cao et al., 2017; Zhang et al., 2018; Cao et al., 2020), but no publications have been issued about the effects of heat stress.

Sucrose is an important carbohydrate in all plants, which has many functions as a storage compound, in regulating respiration and photosynthesis as well as in maintaining the osmotic pressure in plant cytosol (Xu et al., 2010). It is reported also that sucrose may act as a key signaling molecule in strawberry fruit ripening (Jia et al., 2013; Li et al., 2016; Luo et al., 2019, 2020). Sucrose also may play a part in the germination regulation and seedling development as a signaling molecule, although sucrose might readily convert into glucose and fructose (Xu et al., 2010). Sucrose has been applied in tomato production several years ago (Went and Carter, 1948) in order to inhibit the expansion of selected tomato fruits (Bussières et al., 2011), improve tomato seedlings quality (Javanmardi and Emami, 2013) and accelerate the postharvest of 
tomato fruit ripening ( $\mathrm{Li}$ et al., 2016), but there have been no published studies about using sucrose in tomato seedlings under heat stress.

Probiotics could be defined based on the World Health Organization (WHO) as "live microorganisms which when administered in adequate amounts confer a health benefit on the host" (van der Geest et al., 2020). The term of plant probiotics has been used to characterize the "living plant-associated microorganisms", by which the growth of the host plant could be enhanced using adequate amount applied (Islam and Hossain, 2012). Plant probiotic microorganisms are beneficial microorganisms, which could reduce the problems of the environment and also known as bio-fertilizers, bio-controllers, bioprotectants, or bio-stimulants (Vandenberghe et al., 2017). Many studies used plant probiotics emphasizing their role in the agroecosystems (Kumar et al., 2017), such as to enhance plant growth and resistance of diseases (Jayakumar et al., 2019), but still further studies are needed on the growth of tomato seedling under heat stress (De Palma et al., 2017).

Therefore, the aim of this study was to improve the growth and quality of tomato seedlings under heat stress using plant probiotics as well as the individual application of sucrose, silicon and paclobutrazol.

\section{Materials and methods}

\section{Plant materials and growth conditions}

Two experiments were carried out during summer seasons of 2017 and 2018 (during July and August) under plastic greenhouse conditions in a private nursery in Qulin district, Kafr El-Sheikh Governorate, Egypt. The mean maximum and minimum air temperatures and relative humidity inside this greenhouse during the experiments were recorded daily as a mean to be $45 / 27^{\circ} \mathrm{C}$ during day/night and 55 to $80 \%$, respectively. Tomato seeds, super strain B variety were sown in seedling trays (209 cell). This variety is early maturing and produces oval/square fruits hybrid that could weigh up to $140 \mathrm{~g}$ and is vastly used for processing market all over the world, typically with dual purposes. It is resistant to Verticillium wilt, gray leaf spot and Fusarium wilt. These trays were filled with the commercial medium of the coco peat and vermiculite $(1: 1$ volume), that was mixed with $300 \mathrm{~g}$ ammonium sulphate $(20 \% \mathrm{~N})+150 \mathrm{~g}$ potassium sulphate $\left(\begin{array}{llllll}48 \% & \mathrm{~K}_{2} \mathrm{O}\end{array}\right)+400 \mathrm{~g}$ calcium super phosphate $\left(\begin{array}{lll}15.5 \% & \mathrm{P}_{2} \mathrm{O}_{5}\end{array}\right)+50 \mathrm{~g}$ micronutrients $+4 \mathrm{~g}$ calcium carbonate $+50 \mathrm{~g}$ fungicide. All previous components were mixed well during preparation the media mixture. The mixture must be well moisturized and filled well in the seedling trays. Tomato seedlings were watered daily and fertilized weekly with recommended nutrients solution. It is worth to mention that, the optimum temperature for tomato seedlings growth ranges from 18 to $30^{\circ} \mathrm{C}$, whereas the growing of seedling may stop when it increases over $35^{\circ} \mathrm{C}$.

\section{Treatments and experimental design}

Treatments were arranged in completely randomized design twice in both seasons in three random replicates, each replicate was one tray (209 cells) and actually occupied 153 cells per tray because the edge cells were not used for getting data. These treatments were arranged individually as follows:

\section{Control (untreated).}


2. Silicon ( $\mathrm{Si}$ ) at four concentrations (i.e., 100, 200, 300 and $500 \mathrm{mg} \mathrm{l}^{-1}$ ) were sprayed on seedlings using diatomite $\left(86-89 \% \mathrm{SiO}_{2}\right)$. The diatomite as a source of silicon was bought from Al-Ahram Company.

3. Sucrose at three concentrations (i.e., 2.5, 5 and 10\%) as a commercial product was added with foliar application.

4. Plant probiotics (100 $\left.\mathrm{mg} \mathrm{l}^{-1}\right)$ were imported from Hungary, as a commercial product "Okant-Agro". The ingredients of this product included water, Sustainable Community Development (SCD) microorganisms, bio sugar cane and rock flour.

5. Paclobutrazol (100 $\left.\mathrm{mg} \mathrm{l}^{-1}\right)$ was sprayed three times as a commercial product "New Coltar Super", which contains 25\% paclobutrazol and produced by Starcheam Company, Egypt. Paclobutrazol (PBZ) is a plant growth retardant (as an antagonist of the plant hormone gibberellin) and tri-azole fungicide.

All previous treatments were sprayed on seedlings three times weekly after complete germination. Foliar application was carried out three times on the seedlings after 10, 17 and 24 days from sowing. The first true leaf emerged after 8 days from sowing and the germination of all seeds started after 4-5 days after cultivation. The measured parameters of vegetative growth were recorded after 28 and 35 days from sowing. The seedling parameters were included the height $(\mathrm{cm})$, stem diameter $(\mathrm{mm})$, leaf area $\left(\mathrm{cm}^{2}\right)$, fresh weight of roots and shoots $(\mathrm{g})$, dry weight of roots and shoots $(\mathrm{g})$.

\section{Total chlorophyll and NPK contents in leaves}

Total chlorophyll content was measured by the Soil Plant Analysis Development (SPAD) chlorophyll meter (Minolta, Co., Ltd, Japan), on fully expanded and apical leaves without destroying them. The leaves were dried at $70^{\circ} \mathrm{C}$ until a constant weight, then ground and wet digested using sulfuric acid and hydrogen peroxide. The nitrogen, phosphorus and potassium contents in the digested plant leaves were determined using micro-Kjeldahl method, spectrophotometer and flame photometer, respectively (Sparks et al., 1996).

\section{Statistical analyses}

All the obtained data during both seasons of the study were tabulated and statistically analyzed using Duncan's Multiple Range Test for comparing between means of different treatments according to Snedecor and Cochran (1990). All statistical analyses were performed using analysis of variance technique by means of "M-STAT" computer software package and the means were compared by Duncan's multiple range test.

\section{Results}

The cultivation of tomato in greenhouse has become increasingly popular in Egypt particularly in the winter to avoid unfavorable weather and to protect cultivated seedlings, but in the summer a threat of heat stress may occur. The management of cultivating tomato seedlings under greenhouse or growth chamber has been reported in literatures. This management includes application of spermidine, ascorbic acid, melatonin, and recently proline as well as heat shock treatment of tomato seedlings (Yang et al., 2019). The proline may support the growth of tomato seedlings under 
greenhouse conditions by lowering the hydrogen peroxide and malondialdehyde contents as well as alleviating the damage of high temperature and enhancing water use efficiency (Tonhati et al., 2020). In this study, the foliar application of plant probiotics, silicon, sucrose and paclobutrazol were investigated on tomato seedlings under greenhouse conditions during the highest temperatures in July and August in Egypt. The improvement of seedling growth and quality under such extreme conditions using the previous amendments was the main target of this study.

\section{Seedling vegetative growth}

The production of vegetables in particular tomato under large protected cultivation area has developed in recent years seeking for controlled intensive production. However, many serious problems have been established causing several stresses (e.g., heat, man-made- and secondary-soil salinization) in arid and semi-arid regions due to the intensive use of chemical fertilizers and unreasonable crop rotation (Li et al., 2015). The heat stress or rising temperature under greenhouse atmosphere has become a crucial problem that threatens the production of tomato and other vegetables under the protected cultivation zones particularly in the summer. Therefore, new approaches should be adopted to overcome the heat stress in particular under greenhouse production of tomato seedlings like silicon, sucrose, and plant probiotics as investigated in the current study.

The foliar applications of bio- (i.e., plant probiotics) and agro-chemical compounds (i.e., sucrose, silicon and paclobutrazol) on tomato seedlings after 28 and 35 days from sowing were impacted in general on the most studied treatments in both seasons (Table 1). Silicon is an important element, which already has been confirmed its mitigation role under biotic (e.g., pests and pathogens) and abiotic stresses (e.g., drought, salinity, etc.) such as salinity (Li et al., 2015; Muneer and Jeong, 2015), drought (Cao et al., 2017, 2020), osmotic stress (Ali et al., 2018), high-pH stress (Khan et al., 2019) and water stress (Zhang et al., 2018) as reported by many researchers, but the heat stress on tomato seedlings still needs more studies (Khan et al., 2020).

Different doses of silicon $\left(100,200,300\right.$ and $\left.500 \mathrm{mg} \mathrm{l}^{-1}\right)$ were foliar applied on tomato seedlings under greenhouse conditions. Regarding seedlings height, the tallest significant seedlings $(6.23$ and $13.0 \mathrm{~cm})$ were recorded for the application of probiotics rate of $100 \mathrm{mg} \mathrm{l}^{-1}$ after 28 and 35 days from sowing, respectively in the first season, whereas the non-significant values were 6.1 and $13.3 \mathrm{~cm}$ in the second season. Comparing to the other $\mathrm{Si}$ doses, the silicon dose of $100 \mathrm{mg}^{-1}$ resulted in the shortest seedling, which obtained also from the control and paclobutrazol treatments (Table 1). The values of all studied vegetative parameters of seedlings (leaf area, stem diameter, fresh and dry weight of roots and shoots of seedlings) increased by increasing Si doses (Tables 2 and 3). The application rate $100 \mathrm{mg}^{-1}$ for both silicon and paclobutrazol showed significant differences with control treatment for almost vegetative growth parameters (Table 1).

Sucrose, as a common sugar, produced naturally in plants, consists of two monosaccharides (i.e., fructose and glucose). It is also the main carbon form, which could be translocated in the higher plants. Sucrose also can regulate the genes, which may be involved in metabolism, photosynthesis, and developmental processes in plants (Xu et al., 2010). Sucrose may control the expression level of the "ApL3" gene that is encoded in tomato leaf and fruit as "Adenosine diphosphate (ADP) glucose focal phosphorylase (AGPase)" (Jia et al., 2016). The cultivated plants can use sugar "sucrose" as a source 
for energy in the elongation of roots, initiation of lateral roots and as a compatible solute in roots for the osmotic adjustment (Xu et al., 2010).

Table 1. The foliar application impacts of bio- and agro-chemical compounds on some vegetative growth parameters of tomato seedlings during both seasons (2017 and 2018)

\begin{tabular}{|c|c|c|c|c|c|c|}
\hline \multirow{4}{*}{ Treatments } & \multicolumn{2}{|c|}{ Seedling height $(\mathrm{cm})$} & \multicolumn{2}{|c|}{ Stem diameter $(\mathbf{m m})$} & \multicolumn{2}{|c|}{ Leaf area $\left(\mathrm{cm}^{2}\right)$} \\
\hline & \multicolumn{6}{|c|}{ Sampling date after sowing (day) } \\
\hline & 28 & 35 & 28 & 35 & 28 & 35 \\
\hline & \multicolumn{6}{|c|}{ The first season } \\
\hline Control & $5.67 \mathrm{c}$ & $11.75 \mathrm{c}$ & 2.30 cde & $2.59 \mathrm{efg}$ & 3.90 ef & $7.17 \mathrm{~cd}$ \\
\hline Silicon $\left(100 \mathrm{mg} \mathrm{l}^{-1}\right)$ & $5.70 \mathrm{c}$ & $12.00 \mathrm{c}$ & 2.37 bcde & $2.57 \mathrm{fg}$ & $4.23 \mathrm{~cd}$ & $7.53 \mathrm{bc}$ \\
\hline Silicon $\left(200 \mathrm{mg} \mathrm{l}^{-1}\right)$ & $5.77 \mathrm{bc}$ & $12.91 \mathrm{a}$ & $2.53 \mathrm{ab}$ & $2.56 \mathrm{~g}$ & $4.40 \mathrm{bc}$ & $6.96 \mathrm{de}$ \\
\hline Silicon $\left(300 \mathrm{mg} \mathrm{l}^{-1}\right)$ & $5.87 \mathrm{bc}$ & $12.75 \mathrm{ab}$ & $2.27 \mathrm{de}$ & $2.64 \mathrm{def}$ & $4.37 \mathrm{bc}$ & $7.46 \mathrm{bc}$ \\
\hline Silicon $\left(500 \mathrm{mg} \mathrm{l}^{-1}\right)$ & $5.97 \mathrm{~b}$ & $13.25 \mathrm{a}$ & $2.60 \mathrm{a}$ & $2.66 \mathrm{cde}$ & $4.80 \mathrm{a}$ & $7.60 \mathrm{ab}$ \\
\hline Sucrose $(2.5 \%)$ & $5.87 \mathrm{bc}$ & $12.26 \mathrm{bc}$ & $2.17 \mathrm{e}$ & $2.48 \mathrm{~h}$ & $3.60 \mathrm{f}$ & $6.80 \mathrm{de}$ \\
\hline Sucrose $(5 \%)$ & $5.9 \mathrm{bc}$ & $12.99 \mathrm{a}$ & 2.30 cde & $2.72 \mathrm{c}$ & $4.50 \mathrm{bc}$ & $7.70 \mathrm{ab}$ \\
\hline Sucrose $(10 \%)$ & $5.97 \mathrm{~b}$ & $13.16 \mathrm{a}$ & $2.50 \mathrm{abc}$ & $2.88 \mathrm{~b}$ & $4.80 \mathrm{a}$ & $7.97 \mathrm{a}$ \\
\hline Paclobutrazol, $100 \mathrm{mg} \mathrm{l}^{-1}$ & $5.67 \mathrm{c}$ & $11.75 \mathrm{c}$ & $2.40 \mathrm{abcd}$ & $2.69 \mathrm{~cd}$ & $4.07 \mathrm{de}$ & $6.77 \mathrm{e}$ \\
\hline \multirow[t]{2}{*}{ Probiotics $\left(100 \mathrm{mg} \mathrm{l}^{-1}\right)$} & $6.23 \mathrm{a}$ & $13.0 \mathrm{a}$ & $2.30 \mathrm{cde}$ & $2.96 \mathrm{a}$ & $4.60 \mathrm{ab}$ & $7.80 \mathrm{ab}$ \\
\hline & \multicolumn{6}{|c|}{ The second season } \\
\hline Control & 5.9 & $12.20 \mathrm{~d}$ & $2.1 \mathrm{bc}$ & 2.95 & $3.50 \mathrm{c}$ & $7.1 \mathrm{bc}$ \\
\hline Silicon $\left(100 \mathrm{mg} \mathrm{l}^{-1}\right)$ & 6.0 & $12.27 \mathrm{~d}$ & $2.1 \mathrm{bc}$ & 3.06 & $3.75 \mathrm{abc}$ & $7.1 \mathrm{bc}$ \\
\hline Silicon $\left(200 \mathrm{mg} \mathrm{l}^{-1}\right)$ & 5.9 & $12.40 \mathrm{~cd}$ & $2.4 \mathrm{ab}$ & 3.00 & $3.80 \mathrm{abc}$ & $7.2 \mathrm{abc}$ \\
\hline Silicon $\left(300 \mathrm{mg} \mathrm{l}^{-1}\right)$ & 6.1 & $12.50 \mathrm{~cd}$ & $2.0 \mathrm{c}$ & 3.00 & $4.10 \mathrm{ab}$ & $7.2 \mathrm{abc}$ \\
\hline Silicon $\left(500 \mathrm{mg} \mathrm{l}^{-1}\right)$ & 6.3 & $13.10 \mathrm{ab}$ & $2.6 \mathrm{a}$ & 3.20 & $4.30 \mathrm{a}$ & $7.3 \mathrm{abc}$ \\
\hline Sucrose $(2.5 \%)$ & 6.1 & $12.80 \mathrm{bc}$ & $2.0 \mathrm{c}$ & 3.00 & $3.50 \mathrm{c}$ & $7.1 \mathrm{bc}$ \\
\hline Sucrose $(5 \%)$ & 6.0 & $12.80 \mathrm{bc}$ & $2.3 \mathrm{abc}$ & 3.10 & $4.20 \mathrm{ab}$ & $7.2 \mathrm{abc}$ \\
\hline Sucrose $(10 \%)$ & 6.4 & $13.00 \mathrm{ab}$ & $2.4 \mathrm{ab}$ & 3.20 & $4.30 \mathrm{a}$ & $7.6 \mathrm{a}$ \\
\hline Paclobutrazol, $100 \mathrm{mg} \mathrm{l}^{-1}$ & 6.0 & $11.70 \mathrm{e}$ & $2.1 \mathrm{bc}$ & 3.20 & $3.46 \mathrm{c}$ & $6.9 \mathrm{c}$ \\
\hline Probiotics $\left(100 \mathrm{mg} \mathrm{l}^{-1}\right)$ & 6.1 & $13.30 \mathrm{a}$ & $2.0 \mathrm{c}$ & 3.10 & $3.70 \mathrm{bc}$ & $7.4 \mathrm{ab}$ \\
\hline
\end{tabular}

Means in the same column followed by the same letter are not significantly different according to DMRT at 0.05

Different levels of sucrose $(2.5,5.0$ and 10\%) were foliar applied on tomato seedlings under greenhouse conditions. These levels of sucrose were investigated on different vegetative parameters of tomato seedlings (Table 1). The foliar application of $10 \%$ sucrose showed the highest values of some studied vegetative parameters of tomato seedlings at 28 and 35 days after sowing in both seasons (Table 1). Many studies have shown the positive effects of applied sucrose on growth of seedlings and fruit ripening of tomato and strawberry compared to untreated seedlings or plants (e.g., Jia et al., 2016; Li et al., 2016; Luo et al., 2019, 2020). These results are consistent with Javanmardi and Emami (2013), who found that application of sucrose solutions (25\%) to tomato plants increased fresh and dry weights of shoots and roots. These results in partial agreed with the results from Hassankhah et al. (2014).

Plant probiotics can be defined as live bacteria capable to improve the crop yield, which may reduce or even eliminate chemical fertilizers. Many studies have shown that, 
these bacteria can not improve the growth, but also the quality of foods. These probiotics are useful for human health because they can increase the food content of nutrients and many plant bioactive compounds (Woo and Pepe, 2018). The word "probiotic" is derived from the Greek, meaning 'for life' and has had several different meanings. It induces plant stress resistance and mineralizes soil nutrients which results in enhancement of nutrient uptake by the plant (Menendez and Garcia-Fraile, 2017). Plant probiotics have significantly increased seedling emergence, vigor, plant weight, root system development compared with untreated rice plants (Khan et al., 2017). Also, probiotic bacteria have well-demonstrated mechanisms to support plant growth (Menendez and Garcia-Fraile, 2017). In the current study, the foliar application of plant probiotic had a positive effect on almost all vegetative growth aspects using rate of $100 \mathrm{mg} \mathrm{l}^{-1}$. This impact might be attributed to the biological effect of probiotics as a biofertilizer, which enhances plant growth. Comparing with control, the values of vegetative growth in tomato seedlings have increased with the application of probiotics (Table 1).

Paclobutrazol (PBZ) is a member of the tri-azole group, which represents plant growth regulators. PBZ regulates excessive vegetative growth, establishes high density plantation, enhances flowering and induces early bearing (Gollagi et al., 2019). It may protect the cultivated plants from many environmental stresses such as salinity (Hu et al., 2017; Fan et al., 2020), high temperature (Baninasab and Ghobadi, 2011) and water stress (Mohan et al., 2020) as confirmed by many researchers (e.g., Soumya et al., 2017; Tesfahun, 2018). Paclobutrazol also has the ability to reduce gibberellin levels and affect the microbial population in soils as well as the activity of dehydrogenase enzyme (Gollagi et al., 2019). Concerning paclobutrazol and its impact on tomato seedlings, a few studies involved its inducing tolerance under water deficit stress (Pal et al., 2016) and use paclobutrazol in the production of tomato seedlings (Bene et al., 2014) but there are no investigations on heat stress and tomato seedlings in the presence of paclobutrazol.

In the current study, the foliar application of paclobutrazol had a negative effect on the vegetative growth aspects of tomato seedlings (Table 1). The reason might be due to paclobutrazol is delaying cell division and elongation in tissues of the seedlings. This result was in harmony with the results, which reported by Pal et al. (2016), who confirmed that PBZ application reduced the plant height, the seedling growth rate and consequently the seedlings size under deficit irrigation, whereas PBZ improved leaf number and the stem diameter. The paclobutrazol also has the ability to reduce shoot elongation, leaf expansion and stem diameter growth in many plant species like tomato because it is an active inhibitor of gibberellic acid biosynthesis, therefore it retards the division and elongation of cells, and consequently, growth in plant stem length (de Rezende et al., 2017).

\section{Biomass production of seedlings}

The biomass production of seedlings is the final desired harvest, where the high biomass production may support the seedlings to grow under the environmental stresses. It could be noticed that, the foliar application of plant probiotic $\left(100 \mathrm{mg} \mathrm{l}^{-1}\right)$, silicon $(500$ $\mathrm{mg}^{-1}$ ) and sucrose (10\%) separately have recorded the highest values on tomato seedlings in almost all vegetative growth parameters, whereas the lowest values belonged to the control and $100 \mathrm{mg} \mathrm{l}^{-1}$ of silicon as well as $2.5 \%$ sucrose (Tables 1, 2 and 3). For shoot and root fresh or dry weight, the highest values were recorded by seedlings treated by foliar application of sucrose (10\%) and silicon application $\left(500 \mathrm{mg} \mathrm{l}^{-1}\right)$ in both seasons and treatments 28 and 35 days after sowing. Sucrose treatment at 10\% was produced the 
highest plant fresh weight of seedlings as compared with the control treatment (more than $16 \%$ ), which showed the lowest values in most cases (Table 2). Various results obtained including sucrose on tomato (Javanmardi and Emami, 2013), and sucrose on walnut (Hassankhah et al., 2014) were in harmony with our results. It is noticed also that, there is no publication concerning the role of sucrose, silicon, and plant probiotics on the growth and quality of tomato seedling under heat stress.

Table 2. The foliar application of bio- and agro-chemical compounds on shoot and root fresh weights and the total fresh weight of tomato seedlings during both seasons (2017 and 2018)

\begin{tabular}{|c|c|c|c|c|c|c|}
\hline \multirow{4}{*}{ Treatments } & \multicolumn{2}{|c|}{$\begin{array}{c}\text { Shoot fresh weight } \\
\left(\text { g plant }^{-1}\right)\end{array}$} & \multicolumn{2}{|c|}{$\begin{array}{l}\text { Root fresh weight } \\
\quad\left(\text { g plant }^{-1}\right)\end{array}$} & \multicolumn{2}{|c|}{$\begin{array}{l}\text { Seedling fresh weight } \\
\qquad\left(\mathrm{g} \mathrm{plant}^{-1}\right)\end{array}$} \\
\hline & \multicolumn{6}{|c|}{ Sampling date after sowing (day) } \\
\hline & 28 & 35 & 28 & 35 & 28 & 35 \\
\hline & \multicolumn{6}{|c|}{ The first season } \\
\hline Control & $1.11 \mathrm{~h}$ & $3.20 \mathrm{~cd}$ & $0.30 \mathrm{j}$ & $0.80 \mathrm{j}$ & $1.42 \mathrm{i}$ & $4.04 \mathrm{~h}$ \\
\hline Silicon $\left(100 \mathrm{mg} \mathrm{l}^{-1}\right)$ & $1.25 \mathrm{e}$ & $3.00 \mathrm{e}$ & $0.32 \mathrm{~h}$ & $1.00 \mathrm{~h}$ & $1.60 \mathrm{f}$ & $4.01 \mathrm{i}$ \\
\hline Silicon $\left(200 \mathrm{mg} \mathrm{l}^{-1}\right)$ & $1.29 \mathrm{~d}$ & $3.20 \mathrm{~cd}$ & $0.36 \mathrm{e}$ & $1.03 \mathrm{e}$ & $1.66 \mathrm{e}$ & $4.25 \mathrm{e}$ \\
\hline Silicon $\left(300 \mathrm{mg} \mathrm{l}^{-1}\right)$ & $1.30 \mathrm{~d}$ & $3.40 \mathrm{~b}$ & $0.38 \mathrm{c}$ & $1.05 \mathrm{c}$ & $1.71 \mathrm{c}$ & $4.46 \mathrm{c}$ \\
\hline Silicon $\left(500 \mathrm{mg} \mathrm{l}^{-1}\right)$ & $1.39 \mathrm{~b}$ & $3.58 \mathrm{a}$ & $0.39 \mathrm{~b}$ & $1.12 \mathrm{~b}$ & $1.78 \mathrm{~b}$ & $4.71 \mathrm{~b}$ \\
\hline Sucrose $(2.5 \%)$ & $1.18 \mathrm{f}$ & $3.18 \mathrm{bc}$ & $0.36 \mathrm{f}$ & $1.01 \mathrm{~g}$ & $1.55 \mathrm{~g}$ & $4.10 \mathrm{~g}$ \\
\hline Sucrose $(5 \%)$ & $1.31 \mathrm{~d}$ & $3.32 \mathrm{~g}$ & $0.37 \mathrm{~d}$ & $1.04 \mathrm{~d}$ & $1.69 \mathrm{~d}$ & $4.37 \mathrm{~d}$ \\
\hline Sucrose $(10 \%)$ & $1.45 \mathrm{a}$ & $3.70 \mathrm{a}$ & $0.40 \mathrm{a}$ & $1.14 \mathrm{a}$ & $1.85 \mathrm{a}$ & $4.85 \mathrm{a}$ \\
\hline Paclobutrazol, $100 \mathrm{mg} \mathrm{l}^{-1}$ & $1.13 \mathrm{~g}$ & $2.82 \mathrm{f}$ & $0.31 \mathrm{i}$ & $0.97 \mathrm{i}$ & $1.45 \mathrm{~h}$ & $3.80 \mathrm{j}$ \\
\hline \multirow[t]{2}{*}{ Probiotics $\left(100 \mathrm{mg} \mathrm{l}^{-1}\right)$} & $1.35 \mathrm{c}$ & $3.13 \mathrm{de}$ & $0.34 \mathrm{~g}$ & $1.02 \mathrm{f}$ & $1.70 \mathrm{~cd}$ & $4.16 \mathrm{f}$ \\
\hline & \multicolumn{6}{|c|}{ The second season } \\
\hline Control & $1.12 \mathrm{e}$ & $3.00 \mathrm{~d}$ & $0.26 \mathrm{e}$ & 1.20 & $1.38 \mathrm{e}$ & $4.29 \mathrm{e}$ \\
\hline Silicon $\left(100 \mathrm{mg} \mathrm{l}^{-1}\right)$ & $1.22 \mathrm{~d}$ & $3.03 \mathrm{~d}$ & $0.26 \mathrm{e}$ & 1.20 & $1.49 \mathrm{~d}$ & $4.32 \mathrm{e}$ \\
\hline Silicon $\left(200 \mathrm{mg} \mathrm{l}^{-1}\right)$ & $1.27 \mathrm{~cd}$ & $3.15 \mathrm{c}$ & $0.30 \mathrm{~d}$ & 1.20 & $1.57 \mathrm{~cd}$ & $4.44 \mathrm{~d}$ \\
\hline Silicon $\left(300 \mathrm{mg} \mathrm{l}^{-1}\right)$ & $1.27 \mathrm{~cd}$ & $3.30 \mathrm{~b}$ & $0.34 \mathrm{c}$ & 1.19 & $1.61 \mathrm{c}$ & $4.50 \mathrm{~d}$ \\
\hline Silicon $\left(500 \mathrm{mg} \mathrm{l}^{-1}\right)$ & $1.40 \mathrm{~b}$ & $3.45 \mathrm{a}$ & $0.39 \mathrm{a}$ & 1.30 & $1.80 \mathrm{~b}$ & $4.80 \mathrm{a}$ \\
\hline Sucrose $(2.5 \%)$ & $1.27 \mathrm{~cd}$ & $3.15 \mathrm{c}$ & $0.30 \mathrm{~d}$ & 1.23 & $1.58 \mathrm{c}$ & $4.50 \mathrm{~d}$ \\
\hline Sucrose $(5 \%)$ & $1.43 \mathrm{~b}$ & $3.27 \mathrm{~b}$ & $0.36 \mathrm{~b}$ & 1.30 & $1.81 \mathrm{~b}$ & $4.60 \mathrm{c}$ \\
\hline Sucrose $(10 \%)$ & $1.51 \mathrm{a}$ & $3.54 \mathrm{a}$ & $0.38 \mathrm{a}$ & 1.30 & $1.90 \mathrm{a}$ & $4.84 \mathrm{a}$ \\
\hline Paclobutrazol, $100 \mathrm{mg} \mathrm{l}^{-1}$ & $1.22 \mathrm{~d}$ & $2.85 \mathrm{e}$ & $0.26 \mathrm{e}$ & 1.30 & $1.49 \mathrm{~d}$ & $4.11 \mathrm{f}$ \\
\hline Probiotics $\left(100 \mathrm{mg} \mathrm{l}^{-1}\right)$ & $1.30 \mathrm{c}$ & $3.47 \mathrm{a}$ & $0.30 \mathrm{~d}$ & 1.20 & $1.60 \mathrm{c}$ & $4.70 \mathrm{~b}$ \\
\hline
\end{tabular}

Means in the same column followed by the same letter are not significantly different according to DMRT at 0.05

\section{Total chlorophyll content}

Chlorophyll (Chl) is the essential plant organ for harvesting the light and transducing energy via photosynthesis. Photosynthesis is the main factor in the growth and development of cultivated plants. Under stress, the plants are required to protect the chlorophyll system from the degradation and to sustain Chl biosynthesis, which could be mediated by more than 17 enzymes (Li et al., 2015; Dong et al., 2020). The total 
chlorophyll content in tomato seedlings was investigated using the foliar applications of studied bio- and agro-chemical compounds (Table 4). The foliar application of sucrose (10\%), silicon $\left(500 \mathrm{mg} \mathrm{l}^{-1}\right)$, and plant probiotics $\left(100 \mathrm{mg} \mathrm{l}^{-1}\right)$ significantly increased chlorophyll content, whereas paclobutrazol $\left(100 \mathrm{mg} \mathrm{l}^{-1}\right)$ decreased it or it was equal to the control values. The mean values of $\mathrm{Chl}$ after 28 days were recorded the highest, whereas the values were decreased after 35 days in both seasons. This may be due to 28 days being the optimum date for handling and transportation of seedlings and after that, the chlorophyll content was degraded by time in the nursery. These results are similar to those obtained by Javanmardi and Emami (2013) and Hassankhah et al. (2014), who stated that sucrose can ameliorate stress on chlorophyll of tomato and walnut.

Table 3. The foliar application of bio- and agro-chemical compounds on shoot and root dry weights and the total dry weight of tomato seedlings during both seasons (2017 and 2018)

\begin{tabular}{|c|c|c|c|c|c|c|}
\hline \multirow{4}{*}{ Treatments } & \multicolumn{2}{|c|}{$\begin{array}{l}\text { Shoot dry weight } \\
\left(\text { g plant }^{-1}\right)\end{array}$} & \multicolumn{2}{|c|}{$\begin{array}{l}\text { Root dry weight } \\
\left(\text { g plant }^{-1}\right)\end{array}$} & \multicolumn{2}{|c|}{$\begin{array}{c}\text { Seedling dry weight } \\
\left(\text { g plant }^{-1}\right)\end{array}$} \\
\hline & \multicolumn{6}{|c|}{ Sampling date after sowing (day) } \\
\hline & 28 & 35 & 28 & 35 & 28 & 35 \\
\hline & \multicolumn{6}{|c|}{ The first season } \\
\hline Control & $0.135 \mathrm{~h}$ & $0.425 \mathrm{~h}$ & $0.033 \mathrm{~g}$ & $0.079 \mathrm{i}$ & $0.169 \mathrm{i}$ & $0.505 \mathrm{i}$ \\
\hline Silicon $\left(100 \mathrm{mg} \mathrm{l}^{-1}\right)$ & $0.144 \mathrm{~g}$ & $0.431 \mathrm{~g}$ & $0.036 \mathrm{f}$ & $0.081 \mathrm{~h}$ & $0.180 \mathrm{~h}$ & $0.514 \mathrm{~h}$ \\
\hline Silicon $\left(200 \mathrm{mg} \mathrm{l}^{-1}\right)$ & $0.145 \mathrm{~g}$ & $0.460 \mathrm{~d}$ & $0.038 \mathrm{e}$ & $0.083 \mathrm{~g}$ & $0.185 \mathrm{~g}$ & $0.545 \mathrm{e}$ \\
\hline Silicon $\left(300 \mathrm{mg} \mathrm{l}^{-1}\right)$ & $0.150 \mathrm{e}$ & $0.486 \mathrm{c}$ & $0.039 \mathrm{de}$ & $0.085 \mathrm{f}$ & $0.189 \mathrm{f}$ & $0.572 \mathrm{c}$ \\
\hline Silicon $\left(500 \mathrm{mg} \mathrm{l}^{-1}\right)$ & $0.168 \mathrm{~b}$ & $0.492 \mathrm{~b}$ & $0.045 \mathrm{~b}$ & $0.103 \mathrm{~b}$ & $0.218 b$ & $0.595 \mathrm{~b}$ \\
\hline Sucrose $(2.5 \%)$ & $0.162 \mathrm{~d}$ & $0.430 \mathrm{~g}$ & $0.039 \mathrm{de}$ & $0.088 \mathrm{e}$ & $0.203 \mathrm{~d}$ & $0.519 \mathrm{~g}$ \\
\hline Sucrose $(5 \%)$ & $0.165 \mathrm{c}$ & $0.452 \mathrm{e}$ & $0.040 \mathrm{~d}$ & $0.100 \mathrm{c}$ & $0.207 \mathrm{c}$ & $0.553 \mathrm{~d}$ \\
\hline Sucrose $(10 \%)$ & $0.170 \mathrm{a}$ & $0.496 \mathrm{a}$ & $0.048 \mathrm{a}$ & $0.110 \mathrm{a}$ & $0.222 \mathrm{a}$ & $0.606 \mathrm{a}$ \\
\hline Paclobutrazol, $100 \mathrm{mg} \mathrm{l}^{-1}$ & $0.148 \mathrm{f}$ & $0.402 \mathrm{i}$ & $0.043 \mathrm{c}$ & $0.092 \mathrm{~d}$ & $0.192 \mathrm{e}$ & $0.475 \mathrm{j}$ \\
\hline \multirow[t]{2}{*}{ Probiotics (100 mg l-1) } & $0.150 \mathrm{e}$ & $0.444 \mathrm{f}$ & $0.038 \mathrm{e}$ & $0.086 \mathrm{f}$ & $0.189 \mathrm{f}$ & $0.533 \mathrm{f}$ \\
\hline & \multicolumn{6}{|c|}{ The second season } \\
\hline Control & $0.14 \mathrm{~cd}$ & $0.450 \mathrm{e}$ & $0.025 \mathrm{~b}$ & $0.140 \mathrm{f}$ & $0.160 \mathrm{~d}$ & $0.590 \mathrm{~g}$ \\
\hline Silicon $\left(100 \mathrm{mg} \mathrm{l}^{-1}\right)$ & $0.13 \mathrm{~d}$ & $0.450 \mathrm{e}$ & $0.025 \mathrm{~b}$ & $0.140 \mathrm{f}$ & $0.160 \mathrm{~d}$ & $0.590 \mathrm{~g}$ \\
\hline Silicon $\left(200 \mathrm{mg} \mathrm{l}^{-1}\right)$ & $0.16 \mathrm{c}$ & $0.46 \mathrm{de}$ & $0.030 \mathrm{ab}$ & $0.144 \mathrm{~d}$ & $0.190 \mathrm{bcd}$ & $0.603 \mathrm{f}$ \\
\hline Silicon $\left(300 \mathrm{mg} \mathrm{l}^{-1}\right)$ & $0.17 \mathrm{~b}$ & $0.490 \mathrm{~b}$ & $0.037 \mathrm{~b}$ & $0.148 \mathrm{c}$ & $0.217 \mathrm{abc}$ & $0.637 \mathrm{c}$ \\
\hline Silicon $\left(500 \mathrm{mg} \mathrm{l}^{-1}\right)$ & $0.21 \mathrm{a}$ & $0.520 \mathrm{a}$ & $0.035 \mathrm{ab}$ & $0.154 \mathrm{~b}$ & $0.223 \mathrm{ab}$ & $0.674 \mathrm{~b}$ \\
\hline Sucrose $(2.5 \%)$ & $0.14 \mathrm{~cd}$ & $0.450 \mathrm{e}$ & $0.029 \mathrm{ab}$ & $0.142 \mathrm{e}$ & $0.190 \mathrm{bcd}$ & $0.592 \mathrm{~g}$ \\
\hline Sucrose $(5 \%)$ & $0.200 \mathrm{a}$ & $0.480 \mathrm{bc}$ & $0.033 \mathrm{ab}$ & $0.148 \mathrm{c}$ & $0.230 \mathrm{ab}$ & $0.628 \mathrm{~d}$ \\
\hline Sucrose $(10 \%)$ & $0.210 \mathrm{a}$ & $0.530 \mathrm{a}$ & $0.039 \mathrm{a}$ & $0.158 \mathrm{a}$ & $0.250 \mathrm{a}$ & $0.688 \mathrm{a}$ \\
\hline Paclobutrazol, $100 \mathrm{mg} \mathrm{l}^{-1}$ & $0.140 \mathrm{~cd}$ & $0.470 \mathrm{~cd}$ & $0.030 \mathrm{ab}$ & $0.154 \mathrm{~b}$ & $0.180 \mathrm{~cd}$ & $0.624 \mathrm{~d}$ \\
\hline Probiotics $\left(100 \mathrm{mg} \mathrm{l}^{-1}\right)$ & $0.150 \mathrm{c}$ & $0.470 \mathrm{~cd}$ & $0.030 \mathrm{ab}$ & $0.142 \mathrm{e}$ & $0.180 \mathrm{~cd}$ & $0.610 \mathrm{e}$ \\
\hline
\end{tabular}

Means in the same column followed by the same letter are not significantly different according to DMRT at 0.05

\section{Chemical composition of leaves}

The NPK content in tomato seedling leaves represent one of the most important parameters of seedling quality due to the potentiality of NPK nutrients in several 
metabolic processes. Several parameters could assess the quality of produced seedlings such as the growth rate, biomass accumulation, chlorophyll content, and NPK content. The chemical composition (i.e., NPK contents) of tomato seedlings was investigated using the foliar applications of studied bio- and agro-chemical compounds (Table 4). This chemical composition included the total chlorophyll content in seedlings and NPK contents in leaves as well. Leaf mineral content of tomato seedlings showed that application of both silicon $\left(500 \mathrm{mg} \mathrm{l}^{-1}\right)$ and sucrose (10\%) significantly increased potassium content (3.6 and 3.3\%, respectively) compared to the paclobutrazol treatment, which recorded the lowest value $(2.9 \%)$ in the first season. However, in the second season the application of $\mathrm{Si}\left(500 \mathrm{mg} \mathrm{l}^{-1}\right)$, sucrose $(10 \%)$ and probiotics $\left(100 \mathrm{mg} \mathrm{l}^{-1}\right)$ significantly increased leaf $\mathrm{K}$-content comparing with paclobutrazol treatment, which resulted the lowest values $(2.7 \%)$. The following treatments, which involved foliar applied silicon $\left(500 \mathrm{mg} \mathrm{l}^{-1}\right)$, sucrose $(10 \%)$ and probiotics $\left(100 \mathrm{mg} \mathrm{l}^{-1}\right)$ had statistically the highest $\mathrm{P}$ content in leaves $(0.19 \%)$ of tomato seedlings, while the reverse was true with those sprayed with water (control) or $100 \mathrm{mg} \mathrm{l}^{-1}$ silicon in both seasons $(0.16 \%)$. The same trend was achieved in the case of $\mathrm{N}$-content $(1.9$ and $2.0 \%)$ in seedling leaves for applied Si $\left(500 \mathrm{mg} \mathrm{l}^{-1}\right)$, sucrose $(10 \%)$ and probiotics $\left(100 \mathrm{mg} \mathrm{l}^{-1}\right)$ in the first and second season (1.9 and $2.0 \%)$.

Table 4. The foliar application of bio- and agro-chemical compounds on content of total chlorophyll, N, P and K in tomato seedlings during both seasons (2017 and 2018)

\begin{tabular}{|c|c|c|c|c|c|}
\hline \multirow{3}{*}{ Treatments } & \multicolumn{2}{|c|}{$\begin{array}{c}\text { Total chlorophyll content } \\
\text { (SPAD) }\end{array}$} & \multicolumn{3}{|c|}{ Nutrient content in seedling leaves } \\
\hline & \multicolumn{5}{|c|}{ Sampling after sowing (day) (\%) } \\
\hline & 28 & 35 & $\mathbf{N}$ & $\mathbf{P}$ & $\mathbf{K}$ \\
\hline & \multicolumn{5}{|c|}{ The first season } \\
\hline Control & $4.90 \mathrm{de}$ & $2.97 \mathrm{c}$ & $1.5 \mathrm{e}$ & $0.160 \mathrm{e}$ & $3.2 \mathrm{c}$ \\
\hline Silicon $\left(100 \mathrm{mg} \mathrm{l}^{-1}\right)$ & 4.57 ef & $3.37 \mathrm{ab}$ & $1.7 \mathrm{~cd}$ & $0.160 \mathrm{e}$ & $3.2 \mathrm{c}$ \\
\hline Silicon $\left(200 \mathrm{mg} \mathrm{l}^{-1}\right)$ & $4.43 \mathrm{f}$ & $2.93 \mathrm{c}$ & $1.8 \mathrm{bc}$ & $0.165 \mathrm{de}$ & $3.1 \mathrm{~cd}$ \\
\hline Silicon $\left(300 \mathrm{mg} \mathrm{l}^{-1}\right)$ & $4.63 \mathrm{ef}$ & $3.00 \mathrm{bc}$ & $1.8 \mathrm{bc}$ & $0.175 \mathrm{bc}$ & $3.2 \mathrm{c}$ \\
\hline Silicon $\left(500 \mathrm{mg} \mathrm{l}^{-1}\right)$ & $5.27 \mathrm{bcd}$ & $3.43 \mathrm{a}$ & $1.9 \mathrm{ab}$ & $0.190 \mathrm{a}$ & $3.5 \mathrm{ab}$ \\
\hline Sucrose $(2.5 \%)$ & 4.70 ef & $3.37 \mathrm{ab}$ & $1.7 \mathrm{~cd}$ & $0.170 \mathrm{~cd}$ & $3.0 \mathrm{de}$ \\
\hline Sucrose $(5 \%)$ & $5.63 \mathrm{ab}$ & $3.57 \mathrm{a}$ & $1.9 \mathrm{ab}$ & $0.180 \mathrm{~b}$ & $3.4 \mathrm{~b}$ \\
\hline Sucrose $(10 \%)$ & $5.77 \mathrm{a}$ & $3.73 \mathrm{a}$ & $2.0 \mathrm{a}$ & $0.190 \mathrm{a}$ & $3.6 \mathrm{a}$ \\
\hline Paclobutrazol $\left(100 \mathrm{mg} \mathrm{l}^{-1}\right)$ & $5.23 \mathrm{~cd}$ & $3.37 \mathrm{ab}$ & $1.6 \mathrm{de}$ & $0.180 \mathrm{~b}$ & $2.9 \mathrm{e}$ \\
\hline \multirow[t]{2}{*}{ Probiotics $\left(100 \mathrm{mg} \mathrm{l}^{-1}\right)$} & $5.50 \mathrm{abc}$ & $2.87 \mathrm{c}$ & $1.9 \mathrm{ab}$ & $0.190 \mathrm{a}$ & $3.4 \mathrm{~b}$ \\
\hline & \multicolumn{5}{|c|}{ The second season } \\
\hline Control & $5.8 \mathrm{ab}$ & 3.6 & $1.4 \mathrm{c}$ & $0.160 \mathrm{e}$ & $3.1 \mathrm{abc}$ \\
\hline Silicon $\left(100 \mathrm{mg} \mathrm{l}^{-1}\right)$ & $5.8 \mathrm{ab}$ & 3.8 & $1.6 \mathrm{bc}$ & $0.160 \mathrm{e}$ & $3.0 \mathrm{abc}$ \\
\hline Silicon $\left(200 \mathrm{mg} \mathrm{l}^{-1}\right)$ & $5.8 \mathrm{ab}$ & 3.8 & $1.7 \mathrm{abc}$ & $0.165 \mathrm{de}$ & $3.0 \mathrm{abc}$ \\
\hline Silicon $\left(300 \mathrm{mg} \mathrm{l}^{-1}\right)$ & $6.0 \mathrm{ab}$ & 3.6 & $1.7 \mathrm{abc}$ & 0.168 cde & $2.9 \mathrm{bc}$ \\
\hline Silicon $\left(500 \mathrm{mg} \mathrm{l}^{-1}\right)$ & $6.0 \mathrm{ab}$ & 3.95 & $1.9 \mathrm{ab}$ & $0.175 \mathrm{bcd}$ & $3.3 \mathrm{ab}$ \\
\hline Sucrose $(2.5 \%)$ & $5.8 \mathrm{ab}$ & 3.6 & $1.7 \mathrm{abc}$ & $0.180 \mathrm{abc}$ & $2.9 \mathrm{bc}$ \\
\hline Sucrose $(5 \%)$ & $5.9 \mathrm{ab}$ & 3.9 & $1.8 \mathrm{ab}$ & $0.180 \mathrm{abc}$ & $3.1 \mathrm{abc}$ \\
\hline Sucrose $(10 \%)$ & $6.1 \mathrm{ab}$ & 4.0 & $1.9 \mathrm{ab}$ & $0.189 \mathrm{a}$ & $3.3 \mathrm{a}$ \\
\hline Paclobutrazol, $100 \mathrm{mg} \mathrm{l}^{-1}$ & $5.6 \mathrm{~b}$ & 3.6 & $1.8 \mathrm{ab}$ & $0.185 \mathrm{ab}$ & $2.7 \mathrm{c}$ \\
\hline Probiotics $\left(100 \mathrm{mg} \mathrm{l}^{-1}\right)$ & $6.2 \mathrm{a}$ & 3.7 & $2.0 \mathrm{a}$ & $0.185 \mathrm{ab}$ & $3.3 \mathrm{a}$ \\
\hline
\end{tabular}

Means in the same column followed by the same letter are not significantly different according to DMRT at 0.05 
The regulation of plant growth with synthetic plant growth regulators has become a common agricultural practice. Such available synthetic plant growth regulators, paclobutrazols are potent at low concentrations to inhibit shoot growth and promising in reducing vigor of many species especially under high temperature conditions. Paclobutrazol is a very potent growth retardant that inhibits cell elongation and seems to inhibit gibberellin biosynthesis (Chen et al., 2020). So, paclobutrazol was investigated in this study to get healthy and strong seedlings.

\section{Discussion}

The agricultural production faces a serious threat represented by the climate changes and global warming particularly the raising atmospheric temperature. These high temperatures create heat stress, which may decrease the growth and productivity of many cultivated crops due to extreme damage in plant cells, death in a short time and then the loss in crop yield (Alayafi, 2020). This problem may be accelerated due to the "greenhouse effect". The production of tomato seedlings under greenhouse system may face this problem in particular in arid and semi-arid regions in the summer (mainly July and August), where the temperature is often over $40 \mathrm{C}$ during these months. The optimal growth temperature of tomato ranges from 25 to $30 \mathrm{C}$ during daytime (Zhou et al., 2020). Therefore, the production of tomato seedlings under greenhouse conditions in Egypt needs to manage the projected high temperature stress. This management was carried out in this current study using some biological (plant probiotics) and agrochemical compounds (different doses of silicon and sucrose) comparing with paclobutrazol and control.

Foliar application of silicon (up to $500 \mathrm{mg} \mathrm{l}^{-1}$ ) had positive effects on vegetative growth aspects that might be attributed to the effect of silicon in improving the tolerance of the seedlings to stress, increasing photosynthetic activity, water metabolism, chlorophyll content, antioxidant activities, protecting enzymes and enhancing uptake of necessary nutrients. The exogenous $\mathrm{Si}$ also may alleviate the chlorophyll degradation under stress. The heat stress could mainly affect biochemical reactions in particular restraining the photosynthetic process in plants (Zhou et al., 2017). The foliar application of high level of Si $\left(500 \mathrm{mg} \mathrm{l}^{-1}\right)$ increased vegetative growth parameters (e.g., seedling height and leaf area) due to the beneficial role of Si under stress (Zhang et al., 2017). Silicon also protects the photosynthetic system and chlorophyll from degradation under stress. The photosynthetic damage may include the morphology of stomata and chloroplast, thylakoid electron transport and the fixation of carbon (Dong et al., 2020).

Many vegetables could be produced through the transplanting from seeds germination like tomato, pepper and eggplant. These seedlings should be healthy to get a higher yield. The transplanting process may increase the length of crop season, decrease the risk of adverse environmental conditions and reduce the cost of vegetable production (Javanmardi and Emami, 2013). The foliar application of sucrose up to 10\% resulted in the best values of vegetative growth, biomass accumulation and chlorophyll content as well as NPK content in seedling leaves compared to control in the current study. The sucrose represents an important source for feeding the cultivated seedlings under heat stress because this source may provide seedlings with an additional carbohydrate, which is required for metabolic processes. A pivotal role of sucrose metabolism could be distinguished under biotic and abiotic stress besides its potential in mediation a lot of developmental processes and ripening of tomato fruits ( $\mathrm{Li}$ et al., 2016). Heat stress is 
projected to cause many problems for tomato seedlings on the morphological, physiological (e.g., chlorophyll fluorescence and gas exchange) and biochemical level (e.g., the content of pigments and carbohydrates) as reported by Zhou et al. (2020).

Due to the inappropriate use of agro-chemicals, which has led to intensive degradation in soil and water resources besides environmental pollution, plant probiotics are considered as a crucial approach in the agriculture nowadays (Sohrabi et al., 2020). So, the using of plant probiotics has gained much more attention during the last decades of sustainable agriculture. Plant probiotics could support the cultivated plants through their potential of promoting plant growth, siderophore production, phytohormone biosynthesis, biostimulators, and phosphate solubilization (Menendez and Garcia-Fraile, 2017). These previous approaches may support cultivated plants under stress. The activity of plant probiotics depends on the environmental conditions particularly temperature, it increases with temperature till a limit. In the current study, the foliar application of probiotics recorded high values in vegetative growth, biomass production of tomato seedlings as well as chlorophyll content beside the NPK contents. These high values were nearly like those, which were recorded by applied sucrose (10\%) and silicon (500 mg 1-1). The mechanism may be resulted from solubilizing minerals in soil, which subsequently enhanced growth of plants. In other words, the mechanism may include the action of probiotics as bio-control, bio-fertilization and bio-stimulation, which enhances the plant growth and induces seedlings resistance to abiotic stress. Different managements which tomato seedlings could adapt under heat stress are summarized through a comparison between the current study and some published articles under different growth conditions (Table 5).

Table 5. A comparison between the current study and some published articles concerning heat stress on tomato seedlings and growth conditions

\begin{tabular}{|c|c|c|c|}
\hline $\begin{array}{c}\text { Seedling age at heat } \\
\text { stress treating }\end{array}$ & $\begin{array}{c}\text { Growth conditions and } \\
\text { cultivated } \mathrm{cv} .\end{array}$ & Most important findings of the study & Ref. \\
\hline $\begin{array}{c}\text { At the } 3^{\text {rd }} \text { true leaf, } \\
38 / 28^{\circ} \mathrm{C} \text { day/night for } \\
7 \text { days, spaying } 1 \mathrm{mM} \\
\text { spermidine }\end{array}$ & $\begin{array}{l}\text { Growth chamber and } \\
\text { "cv. Puhong } 968 "\end{array}$ & $\begin{array}{l}\text { Spraying spermidine may alleviate the } \\
\text { damage of heat stress through } \\
\text { enhancing oxidative stress of non- and } \\
\text { enzymatic antioxidants }\end{array}$ & $\begin{array}{l}\text { Sang et al. } \\
\quad(2016)\end{array}$ \\
\hline $\begin{array}{l}\text { At the } 3^{\text {rd }} \text { week old of } \\
\text { seedlings, } 39 / 29^{\circ} \mathrm{C} \\
\text { for } 14 \text { days }\end{array}$ & $\begin{array}{l}\text { Growth chamber and } \\
\text { "cv. Luktho" }\end{array}$ & $\begin{array}{c}\text { Foliar application of the } \mathrm{CaCl}_{2} \text {, } \\
\mathrm{CaNO}_{3}, \mathrm{MgCl}_{2} \text {, or } \mathrm{KNO}_{3} \text { solution } \\
\text { mitigated heat stress effect by reducing } \\
\text { the ROS }\end{array}$ & $\begin{array}{l}\text { Sakhonwasee } \\
\text { and Phingkasan } \\
\text { (2017) }\end{array}$ \\
\hline $\begin{array}{l}\text { Seedlings transferred } \\
\text { into pots, grown for } \\
25 \text { days at } 45 / 32{ }^{\circ} \mathrm{C} \\
\text { (day/night) }\end{array}$ & $\begin{array}{l}\text { Growth chamber, NUN } \\
5024 \text { var., India, seeds } \\
\text { primed in } \mathrm{Mg}\left(\mathrm{NO}_{3}\right)_{2}\end{array}$ & $\begin{array}{c}\text { Priming seeds in } \mathrm{Mg}\left(\mathrm{NO}_{3}\right)_{2} \text { (from } 5 \text { to } \\
10 \mathrm{mM}) \text { may improve germination in } \\
\text { normal }\left(25^{\circ} \mathrm{C}\right) \text { and ameliorate high } \\
\text { temperature stress }\left(40^{\circ} \mathrm{C}\right)\end{array}$ & $\begin{array}{l}\text { Nafees et al. } \\
\quad(2019)\end{array}$ \\
\hline $\begin{array}{l}\text { At the } 4^{\text {th }} \text { true leaf, } \\
\text { seedlings exposed to } \\
42{ }^{\circ} \mathrm{C} \text { for } 24 \mathrm{~h}\end{array}$ & $\begin{array}{l}\text { Growth chamber, cv. } \\
\text { Hezuo } 903 \text {, China, at } \\
28 / 19^{\circ} \mathrm{C}(\text { day/night }), \\
\text { melatonin }(100 \mu \mathrm{M}) \\
\text { sprayed for } 7 \text { days } \\
\end{array}$ & $\begin{array}{l}\text { Melatonin may control over- } \\
\text { accumulation of hydrogen peroxide } \\
\text { and superoxide, then lower the lipid } \\
\text { peroxidation content }\end{array}$ & $\begin{array}{l}\text { Jahan et al. } \\
\text { (2019a) }\end{array}$ \\
\hline $\begin{array}{l}\text { At the } 5^{\text {th }} \text { true leaf, } \\
\text { seedlings exposed to } \\
42{ }^{\circ} \mathrm{C} \text { for } 36 \mathrm{~h}\end{array}$ & $\begin{array}{l}\text { Growth chamber, cv. } \\
\text { Hezuo } 903 \text {, China, at } \\
28 / 19^{\circ} \mathrm{C} \text { (day/night), } \\
\text { salicylic acid ( } 1 \mathrm{mM}) \\
\text { sprayed for } 7 \text { days }\end{array}$ & $\begin{array}{l}\text { Salicylic acid may increase proline } \\
\text { content, the activity of photosynthesis } \\
\text { and antioxidant enzyme functions }\end{array}$ & $\begin{array}{l}\text { Jahan et al. } \\
\text { (2019b) }\end{array}$ \\
\hline
\end{tabular}




\begin{tabular}{c|c|c|l}
\hline $\begin{array}{c}\text { After transfer into } \\
\text { hydroponics, } 40^{\circ} \mathrm{C} \\
\text { for } 8 \mathrm{~h} / \text { day for } 7 \text { days, } \\
\text { applied } 0.5 \mathrm{mM} \text { AsA }\end{array}$ & $\begin{array}{c}\text { Plants were grown in } \\
\text { peat moss for } 35 \text { days, } \\
\text { then transferred into } \\
\text { hydroponic system }\end{array}$ & $\begin{array}{c}\text { Ascorbic acid (AsA) may be } \\
\text { considered a key signaling molecule } \\
\text { that enhances the thermo-tolerance of } \\
\text { tomato seedlings }\end{array}$ & Alayafi (2020) \\
\hline $\begin{array}{c}\text { At } 18^{\text {th }} \text { day-old } \\
\text { seedlings, sprayed 3 } 3\end{array}$ & $\begin{array}{c}\text { In greenhouse, super } \\
\text { strain B variety, under } \\
\text { times and sampling } \\
\text { after } 4 \text { and 5 weeks }\end{array}$ & $\begin{array}{c}\text { Foliar application of sucrose, silicon } \\
\text { and plant probiotics improved the } 40 / 25^{\circ} \mathrm{C} \\
\text { (day/night) for } 35 \text { days }\end{array}$ & $\begin{array}{c}\text { growth and quality of seedlings } \\
\text { Current study }\end{array}$ \\
\hline
\end{tabular}

\section{Conclusion}

The planet suffers from the climate changes and global warming, which lead to increase in the atmospheric temperature especially under the greenhouse conditions. Under the conditions of Egypt, the production of vegetables under greenhouse systems particularly tomato seedlings during the highest temperatures (mainly July and August) is a great challenge due to the heat stress. So, this production should be managed through the application of proper amendments including the agro-chemical (e.g., Si, Se, $\mathrm{Ca}, \mathrm{Mg}$ ), organic (e.g., sucrose, spermidine, ascorbic acid, melatonin and proline) and biological candidates (e.g., plant probiotics). Therefore, this current study was carried out to improve the growth and production of tomato seedlings under greenhouse conditions during the highest temperatures in Egypt (i.e., July and August). This investigation demonstrated that the growth and quality of tomato seedlings under greenhouse conditions could protect the chlorophyll system against heat stress through foliar application of silicon $\left(500 \mathrm{mg} \mathrm{l}^{-1}\right)$, sucrose (10\%), probiotics $\left(100 \mathrm{mg} \mathrm{l}^{-1}\right)$ and paclobutrazol $\left(100 \mathrm{mg} \mathrm{l}^{-1}\right)$ as well. At the same time, the quality of produced tomato seedlings also could be enhanced by the application of previous treatments to include the content of seedlings of NPK. These NPK could guarantee many metabolic processes in leaves of tomato seedlings such as proteins synthesis $(\mathrm{N})$, the cellular division and formation of energetic structures $(\mathrm{P})$ and the control of stomata closure, transportation of sugars, also it increases the tolerance to stress $(\mathrm{K})$. It could be concluded also that, the foliar application of $\mathrm{Si}$, sucrose, probiotics and paclobutrazol are effective on the production of tomato seedlings under heat stress. Further studies are needed to emphasize this role in separate and combined or multiple stresses.

Acknowledgements. The Authors thank the staff members of Physiology and Breeding of Horticultural Crops Laboratory, Dept. of Horticulture, Fac. of Agric., Kafrelsheikh University, Kafr El-Sheikh, Egypt for supporting this study as well as their help in completing this work.

\section{REFERENCES}

[1] Alayafi, A. A. M. (2020): Exogenous ascorbic acid induces systemic heat stress tolerance in tomato seedlings: transcriptional regulation mechanism. - Environmental Science and Pollution Research 27: 19186-19199.

[2] Ali, N., Schwarzenberg, A., Yvin, J.- C., Hosseini, S. A. (2018): Regulatory role of silicon in mediating differential stress tolerance responses in two contrasting tomato genotypes under osmotic stress. - Front. Plant Sci. 8(9): 1475.

[3] Alturki, S. M., Shalaby, T. A., Almadini, A. M., El-Ramady, H. R. (2020): The nutritional status of tomato seedlings and peroxidase activity under foliar applications of some biostimulants. - Fresen Environ Bull. 29: 421-433. 
[4] Baninasab, B., Ghobadi, C. (2011): Influence of paclobutrazol and application methods on high-temperature stress injury in cucumber seedlings. - J Plant Growth Regul. 30(2): 213-219.

[5] Bene, K. S. S., De Araújo Faria, M. J., Seleguini, C. G. S. A., Lemos, O. L. (2014): Use of paclobutrazol in the production of tomato seedlings. - Comunicata Scientiae 5(2): 164169.

[6] Bian, Z., Zhang, X., Wang, Y., Lu, C. (2019): Improving drought tolerance by altering the photosynthetic rate and stomatal aperture via green light in tomato (Solanum lycopersicum L.) seedlings under drought conditions. - Environ Exp Bot. 167: 103844.

[7] Bilal, S., Shahzad, R., Imran, M., Jan, R., Min, K., Kim, Lee, I.-J. (2020): Synergistic association of endophytic fungi enhances Glycine $\max \mathrm{L}$. resilience to combined abiotic stresses: heavy metals, high temperature and drought stress. - Ind Crops Prod. 143: 111931.

[8] Bussières, P., Bertin, N., Morris, C. E., Vigne, C., Orlando, P., Glaux, C., Sévenier, V., Floret, H., Bernadac, J., Korownikoff, S. (2011): High external sucrose concentration inhibits the expansion of detached tomato fruits grown in a novel semi-open device. - In Vitro Cell. Dev. Biol.-Plant 47: 743-751.

[9] Cao, B., Wang, L., Gao, S., Xia, J., Xu, K. (2017): Silicon-mediated changes in radial hydraulic conductivity and cell wall stability are involved in silicon-induced drought resistance in tomato. - Protoplasma 254(6): 2295-2304.

[10] Cao, B., Ma, Q., Xu, K. (2020): Silicon restrains drought-induced ROS accumulation by promoting energy dissipation in leaves of tomato. - Protoplasma 257: 537-547.

[11] Chen, S., Wang, X.-J., Tan, G.-F., Zhou, W.-Q., Wang, G.-L. (2020): Gibberellin and the plant growth retardant Paclobutrazol altered fruit shape and ripening in tomato. Protoplasma 257: 853-861.

[12] De Palma, M., D’Agostino, N., Proietti, S., Bertini, L., Lorito, M., Ruocco, M., Chiusano, M. L., Tucci, M. (2017): Suppression subtractive hybridization analysis provides new insights into the tomato (Solanum lycopersicum L.) response to the plant probiotic microorganism Trichoderma longibrachiatum MK1. - J Plant Physiol 190: 79-94.

[13] de Rezende, É. M., Oliveira, J. A., Carvalho, E. R., Clemente, A. da C. S., Oliveira, G. E. (2017): Physiological quality of tomato seeds treated with polymers in combination with paclobutrazol. - J Seed Sci 39(4): 338-343.

[14] Dong, Z., Men, Y., Liu, Z., Li, J., Ji, J. (2020): Application of chlorophyll fluorescence imaging technique in analysis and detection of chilling injury of tomato seedlings. Comput Electron Agric. 168: 105109.

[15] Elkelish, A. A., Alhaithloul, H. A. S., Qari, S. H., Soliman, M. H., Hasanuzzaman, M. (2020): Pretreatment with Trichoderma harzianum alleviates waterlogging-induced growth alterations in tomato seedlings by modulating physiological, biochemical, and molecular mechanisms. - Environ Exp Bot. 171: 103946.

[16] El-Shafeey, E. I., El-Khateeb, N. M., Elsharkawy, M. M., Elsary, G. S. Homayed, S. H. (2019): Induction of systemic resistance against Meloidgyene incognita by different chemical and biological inducers in tomato plants. - Fresen Environ Bull. 28: 6692-6670.

[17] Fahad, S., Bajwa, A. A., Nazir, U., Anjum, S. A., Farooq, A., Zohaib, A., Sadia, S., Nasim W., Adkins S., Saud Shah, Ihsan, M. Z., Alharby H., Wu, C., Wang, D., Huang, J. (2017): Crop production under drought and heat stress: plant responses and management options. - Front Plant Sci. 8: 1147.

[18] Fan, Z. X., Li, S. C., Sun, H. L. (2020): Paclobutrazol modulates physiological and hormonal changes in Amorpha fruticosa under drought stress. - Russ J Plant Physiol. 67: 122-130.

[19] FAOSTAT (2020): Crops: tomatoes. - http://www.fao.org/faostat/en/\#data/QC. Accessed on 24 March, 2020.

[20] FAO (2017): Good agricultural practices for greenhouse vegetable production in the South East European countries. Principles for sustainable intensification of smallholder 
farms. - FAO Plant Production and Protection Paper. Vol. 230. Food and Agriculture Organization of the United Nations (FAO), Rome.

[21] Gama, P. B. S., Wani, L. B., Marcelo, P. W., Ragga, D., Misaka, B. C. (2015): Effect of soil media on growth of tomato seedlings (Solanum lycopersicum L.) under nursery (Greenhouse) conditions. - Int J Agri Res and Review 3(10): 432-439.

[22] Gollagi, S. G., Jasmitha, B. G., Sreekanth, H. S. (2019): A review on: paclobutrazol a boon for fruit crop production. - J Pharmacognosy and Phytochemistry 8(3): 2686-2691.

[23] Hassankhah, A., Vahdati, K., Lotfi, M., Mirmasoumi, M., Preece, J., Assareh, M.-H. (2014): Effects of ventilation and sucrose concentrations on the growth and plantlet anatomy of micropropagated Persian walnut plants. - Int J Hort. Sci Tech 1(2): 111-120.

[24] Hossain, M. A., Liu, F. D., Burritt, J., Fujita, M., Huang, B. (2020): Priming-Mediated Stress and Cross-Stress Tolerance in Crop Plants. - Elsevier, Cambridge, MA.

[25] Hu, Y., Yu, W., Liu, T., Shafi, M., Song, L., Du, X., Huang, Y., Yue, Wu, J. (2017): Effects of paclobutrazol on cultivars of Chinese bayberry (Myrica rubra) under salinity stress. - Photosynthetica 55(3): 443-453.

[26] Islam, M. T., Hossain, M. M. (2012): Plant Probiotics in Phosphorus Nutrition in Crops, with Special Reference to Rice. - In: Maheshwari, D. K. (ed.), Bacteria in Agrobiology: Plant Probiotics. Springer, Berlin, pp: 325-363. DOI 10.1007/978-3-642-27515-9_18.

[27] Jahan, M. S., Shu, S., Wang, Y., Chen, Z., He, M., Tao, M., Sun, J., Guo, S. (2019a): Melatonin alleviates heat-induced damage of tomato seedlings by balancing redox homeostasis and modulating polyamine and nitric oxide biosynthesis. - BMC Plant Biol 19(1): 414.

[28] Jahan, M. S., Wang, Y., Shu, S., Zhong, M., Chen, Z., Wu, J., Sun J., Guo, S. (2019b): Exogenous salicylic acid increases the heat tolerance in Tomato (Solanum lycopersicum L.) by enhancing photosynthesis efficiency and improving antioxidant defense system through scavenging of reactive oxygen species. - Scientia Horticulturae 247: 421-429.

[29] Javanmardi, J., Emami, S. (2013): Application of sucrose on tomato seedlings improves transplant quality, crop establishment, cold and dark hardiness. - Adv. Hort. Sci. 27(3): 122-126.

[30] Jayakumar, A., Krishna, A., Mohan, M., Nair, I. C., Radhakrishnan, E. K. (2019): Plant growth enhancement, disease resistance, and elemental modulatory effects of plant probiotic endophytic Bacillus sp. Fcl1. - Probiotics Antimicrob Proteins 11: 526-534.

[31] Jia, H., Wang, Y., Sun, M., Li, B., Han, Y., Zhao, Y., Li, X., Ding, N., Li, C., Ji, W., Jia, W. (2013): Sucrose functions as a signal involved in the regulation of strawberry fruit development and ripening. - New Phytolo 198(2): 453-465.

[32] Jia, H., Jiu, S., Zhang, C., Wang, C., Tariq, P., Liu, Z., Wang, B., Cui, L., Fang, J. (2016): Abscisic acid and sucrose regulate tomato and strawberry fruit ripening through the abscisic acid-stress-ripening transcription factor. - Plant Biotechnol J. 14(10): 2045-65.

[33] Khan, A., Kamran, M., Imran, M., Al-Harrasi, A., Al-Rawahi, A., Al-Amri, I., Lee, I.-J., Khan, A. L. (2019): Silicon and salicylic acid confer high-pH stress tolerance in tomato seedlings. - Sci Rep. 9: 19788.

[34] Khan, A., Khan, A. L., Imran, M., Asaf, S., Kim, Y.-H., Bilal, S., Numan, M., Al-Harrasi, A., Al-Rawahi, A., Lee, I.-J. (2020): Silicon-induced thermotolerance in Solanum lycopersicum L. via activation of antioxidant system, heat shock proteins, and endogenous phytohormones. - BMC Plant Biol 20: 248.

[35] Khan, M. M. A., Haque, E., Paul, N. C., Khaleque, M. A., Al-Garni, S. M. S., Rahman, M., Islam, M. T. (2017): Enhancement of growth and grain yield of rice in nutrient deficient soils by rice probiotic bacteria. - Rice Sci 24(5): 264-273.

[36] Kumar, V., Kumar, M., Sharma, S., Prasad, R. (2017): Probiotics in Agroecosystem. Springer Nature, Singapore.

[37] Li, D., Mou, W., Wang, Y., Li, L., Mao, L., Ying, T., Luo, Z. (2016): Exogenous sucrose treatment accelerates postharvest tomato fruit ripening through the influence on its 
metabolism and enhancing ethylene biosynthesis and signaling. - Acta Physiol Plantarum 38(9): 225.

[38] Li, H., Zhu, Y., Hu, Y., Han, W., Gong, H. (2015): Beneficial effects of silicon in alleviating salinity stress of tomato seedlings grown under sand culture. - Acta Physiol Plant 37: 71.

[39] Li, J., Hu, L., Zhang, L., Pan, X., Hu, X. (2015): Exogenous spermidine is enhancing tomato tolerance to salinity-alkalinity stress by regulating chloroplast antioxidant system and chlorophyll metabolism. - BMC Plant Biology 15(1): 303.

[40] Liu, X., Zhang, Q., Yang, G., Zhang, C., Dong, H., Liu, Y., Yin, R., Lin, L. (2020): Pivotal roles of Tomato photoreceptor SIUVR8 in seedling development and UV-B stress tolerance. - Biochem Biophys Res Commun. 522(1): 177-183.

[41] Luo, Y., Lin, Y., Mo, F., Ge, C., Jiang, L., Zhang, Y., Chen, Q., Sun, B., Wang, Y., Wang, X., Tang, H. (2019): Sucrose promotes strawberry fruit ripening and affects ripening-related processes. - Int J Genomics 2019: 9203057.

[42] Luo, Y., Ge, C., Ling, Y., Mo, F., Yang, M., Jiang, L., Chen, Q., Lin, Y., Sun, B., Zhang, Y., Wang, Y., Li, M., Wang, X., Tang, H. (2020): ABA and sucrose co-regulate strawberry fruit ripening and show inhibition of glycolysis. - Mol Genet Genomics 295(2): 421-438.

[43] Lyu, J. I., Park, J. H., Kim, J.-K., Bae, C.-H., Jeong, W.-J., Min, S. R., Liu, J. R. (2018): Enhanced tolerance to heat stress in transgenic tomato seeds and seedlings overexpressing a trehalose-6-phosphate synthase/phosphatase fusion gene. - Plant Biotechnol Rep. 12: 399-408.

[44] Menendez, E., Garcia-Fraile, P. (2017): Plant probiotic bacteria: solutions to feed the world. - AIMS Microbiol. 3(3): 502-524.

[45] Mohan, R., Kaur, T., Bhat, H. A., Khajuria, M., Pal, S., Vyas, D. (2020): Paclobutrazol induces photochemical efficiency in mulberry (Morus alba L.) under water stress and affects leaf yield without influencing biotic interactions. - J Plant Growth Regul. 39: 205215.

[46] Muneer, S., Jeong, B. R. (2015): Proteomic analysis of salt-stress responsive proteins in roots of tomato (Lycopersicon esculentum L.) plants towards silicon efficiency. - Plant Growth Regul. 77(2): 133-146.

[47] Nafees, K., Kumar, M., Bose, B. (2019): Effect of different temperatures on germination and seedling growth of primed seeds of tomato. - Russ J Plant Physiol 66(5): 778-784.

[48] Pal, S., Zhao, J., Khan, A., Yadav, N. S., Batushansky, A., Barak, S., Rewald B., Fait A., Lazarovitch N., Rachmilevitch, S. (2016): Paclobutrazol induces tolerance in tomato to deficit irrigation through diversified effects on plant morphology, physiology and metabolism. - Sci Rep. 6(1): 39321.

[49] Sakhonwasee, S., Phingkasan, W. (2017): Effects of the foliar application of calcium on photosynthesis, reactive oxygen species production, and changes in water relations in tomato seedlings under heat stress. - Hort Environ Biotechnol 58(2): 119-126.

[50] Sang, Q. Q., Shu, S., Shan, X., Guo, S. R., Sun, J. (2016): Effects of exogenous spermidine on antioxidant system of tomato seedlings exposed to high temperature stress. - Russ J Plant Physiol 63(5): 645-655.

[51] Snedecor, G. W., Cochran, W. G. (1990): Statistical Methods. $8^{\text {th }}$ Ed. - Iowa State Univ. Press, Ames.

[52] Sohrabi, F., Sheikholeslami, M., Heydari, R., Rezaee, S., Sharif, R. (2020): Investigating the effect of Glomus mosseae, Bacillus subtilis and Trichoderma harzianum on plant growth and controlling Meloidogyne javanica in tomato. - Indian Phytopathol 73: 293300 .

[53] Soumya, P. R., Kumar, P., Pal, M. (2017): Paclobutrazol: a novel plant growth regulator and multi-stress ameliorant. - Indian J Plant Physiol 22(3): 267-278.

[54] Sparks, D. L., Page, A. L., Helmke, P. A., Loeppert, R. H., Soltanpour, P. N., Tabatabai, M. A., Johnston, C. T., Sumner, M. E. (1996): Methods of Soil Analysis. Part 3. 
Chemical Methods. - Soil Science Society of America, Inc. American Society of Agronomy, Inc. Madison, WI.

[55] Tesfahun, W. (2018): A review on: response of crops to paclobutrazol application. Cogent Food \& Agriculture 4(1): 1525169.

[56] Tonhati, R., Mello, S. C., Momesso, P. R., Pedroso, M. (2020): L-proline alleviates heat stress of tomato plants grown under protected environment. - Sci Hortic 268: 109370.

[57] van der Geest, A. M., Flach, J., Claassen, E., Sijlmans, A. W., van de Burgwal, L. H. M., Larsen, O. F. A. (2020): European general practitioners perceptions on probiotics: results of a multinational survey. - Pharma Nutrition 11: 100178.

[58] Vandenberghe, L. P., Garcia, L. M. B., Rodrigues, C., Camara, M. C., de M Pereira, G. V., de Oliveira, J., Socco, C. R. (2017): Potential applications of plant probiotic microorganisms in agriculture and forestry. - AIMS Microbiol 3(3): 629-648.

[59] Went, F., Carter, M. (1948): Growth response of tomato plants to applied sucrose. - Am J Bot 35(2): 95-106.

[60] Woo, S. L., Pepe, O. (2018): Microbial consortia: promising probiotics as plant biostimulants for sustainable agriculture. - Front Plant Sci. 9: 1-6.

[61] Xu, F., Tan, X., Wang, Z. (2010): Effects of sucrose on germination and seedling development of Brassica napus. - Int J Biol 2(1): 1-5.

[62] Yang, Z. Q., Xu, C., Wang, M. T., Zhao, H. L., Zheng, Y. J., Huang, H. J., Vuguziga, F., Umuton, M. A. (2019): Enhancing the thermotolerance of tomato seedlings by heat shock treatment. - Photosynthetica 57(4): 1184-1192.

[63] Zargar, S. M., Mahajan, R., Bhat, J. A., Nazir, M., Deshmukh, R. (2019): Role of silicon in plant stress tolerance: opportunities to achieve a sustainable cropping system. -3 Biotech 9: 73.

[64] Zhang, W., Xie, Z., Lang, D., Cui, J., Zhang, X. (2017): Beneficial effects of silicon on abiotic stress tolerance in legumes. - J Plant Nutr 40(15): 2224-2236.

[65] Zhang, Y., Shi, Y., Gong, H.-J., Zhao, H.-L., Wang, Y.-C. (2018): Beneficial effects of silicon on photosynthesis of tomato seedlings under water stress. - J Integrative Agriculture 17(10): 2151-2159.

[66] Zhang, Y., Zhou, Y., Chen, S., Liu, J., Fan, K., Li, Z., Liu, Z., Lin, W. (2019): Gibberellins play dual roles in response to phosphate starvation of tomato seedlings, negatively in shoots but positively in roots. - J Plant Physiol 234-235: 145-153.

[67] Zhao, J., Rewald, B., Lazarovitch, N., Rachmilevitch, S. (2017): Plasticity of biomass allometry and root traits of two tomato cultivars under deficit irrigation $\mathrm{X}$ chemically induced drought hardening by Paclobutrazol. - Irrigation Sci 35(6): 501-514.

[68] Zhou, R., Yu, X., Ottosen, C.-O., Rosenqvist, E., Zhao, L., Wang, Y., Wang, Y., Yu, W., Zhao, T., Wu, Z. (2017): Drought stress had a predominant effect over heat stress on three tomato cultivars subjected to combined stress. - BMC Plant Biol 17(1): 24.

[69] Zhou, R., Yu, X., Li, X., Mendanha dos Santos, T., Rosenqvist, E., Ottosen, C.-O. (2020): Combined high light and heat stress induced complex response in tomato with better leaf cooling after heat priming. - Plant Physiol Biochem 151: 1-9.

[70] Zhou, Y., Diao, M., Chen, X., Cui, J., Pang, S., Li, Y., Hou, C., Liu, H. (2019): Application of exogenous glutathione confers salinity stress tolerance in tomato seedlings by modulating ions homeostasis and polyamine metabolism. - Sci Hort 250: 45-58. 